\title{
PENGARUH GAYA ARSITEKTUR BANGUNAN INDIS TERHADAP ASPEK SOSIAL DAN BUDAYA MASYARAKAT KABUPATEN BOYOLALI
}

\author{
Ibnu Rustamji \\ Universitas Sebelas Maret \\ email: benuvanimhoff@gmail.com
}

\begin{abstract}
This study aims to reveal the problems underlying the Indis architectural Style in Boyolali 1910 to 1915 which had been located at the city center and its socio-cultural influences to society living in Boyolali village. The problems formulated in this study are to know the historical background of Boyolali City, the development of architectural style, and its social and cultural impact towards the Indis building in Boyolali. Based on the formulated problems above, this study was methodologically designed with historical research which typically divided into heuristics, source criticism, interpretation, and historiography. The results revealed that during 1910 to 1915 the Indis architectures played a major impact on the dynamics of Boyolali where it was the dwelling place between two different civilizations of European and indigenous cultures. The Indis architectural style buildings in Boyolali are observable at the city center in Pandanaran street of Boyolali, and around Merapi and Merbabu street. The physical appearance of the Indis architectural style found in the city sufficiently brought major changes in the society which is identifiable both culturally and socially. Among the cultural impacts were reflected through the people's language use, science and architecture. Additionally, the Indis building brought social impacts to the society among others the emergence of both social class and social status within the people which take into account the architectural style, Indis style and education.
\end{abstract}

Keywords: Indis architectural, Boyolali, social and culture impact

\begin{abstract}
ABSTRAK
Penelitian ini bertujuan untuk untuk mengetahui gaya arsitektur bangunan Indis yang berada di pusat Kota Boyolali dan pengaruhnya terhadap dinamika sosial budaya masyarakat Kabupaten Boyolali tahun 1910-1915. Rumusan masalah penelitan ini adalah (1) latar belakang berdirinya Kabupaten Boyolali, (2) perkembangan gaya arsitektur Indis di Boyolali tahun 1910-1915, dan (3) pengaruh gaya arsitektur Indis terhadap dinamika sosial dan budaya masyarakat Kabupaten Boyolali. Sejalan dengan rumusan masalah tersebut, penelitian ini menggunakan metode sejarah, diantaranya heuristik, kritik sumber, intepretasi, dan historiografi. Teknik pengumpulan data dilakukan melalui studi dokumen dan studi pustaka. Hasil penelitian menunjukkan bahwa selama kurun waktu 1910-1915, arsitektur Indis memiliki pengaruh cukup besar terhadap dinamika Kabupaten Boyolali, yakni pertemuan dua budaya, antara budaya Eropa dan pribumi sehingga muncul perpaduan antara arsitektur Jawa dan Eropa melalui ornamen struktur bangunan. Contohnya adalah Gedung Soos, Tangsi Militer, Landraad, dan rumah sakit militer ataupun rumah pribadi orang Eropa, hotel dan villa. Dampak dari hal itu tercermin dalam pengunaan bahasa, arsitektur, dan ilmu pengetahuan. Dampak sosial adalah kemunculan golongan dan status sosial masyarakat yang didasarkan atas gaya arsitektur tempat tinggal, gaya hidup Indis, dan pendidikan.
\end{abstract}

Kata kunci: gaya arsitektur bangunan Indis, Kota Boyolali, dampak sosial dan budaya 


\section{PENDAHULUAN}

Kota tidak dapat dipisahkan dari perkembangan desa di Indonesia yang ditandai dengan budaya masyarakat yang saling berhubungan dan berkomunikasi. Hal ini akhirnya melahirkan sistem pengetahuan, budaya, sosial, ekonomi, dan politik dan hingga melahirkan budaya kota (Basundoro, 2012: 19). Syarat berdirinya sebuah kota harus memperhatikan beberapa unsur, di antaranya unsur internal yakni kondisi geografis, sosial, budaya dan politik masyarakat. Sementara itu, unsur eksternal adalah proses urbanisasi. Perkembangan kota di Indonesia dimulai setelah berdirinya beberapa Ibukota kerajaan di beberapa wilayah. Diantaranya adalah Trowulan yang merupakan Ibukota Kerajaan Majapahit, Banten yang merupakan Ibukota Kerajaan Banten dan Kotagede yang merupakan Ibukota Kerajaan Mataram Awal (Yunus, 2004: 16).

Kota di Indonesia selalu berkembang seiring berjalannya waktu. Selain didasarkan kepada unsur pembentuk kota, kriteria itu juga didasarkan pada unsur morfologi pembentuk kota. Unsur itu adalah penggunaan lahan, pola konstruksi jalan, dan gaya bangunan. Awal mula berdirinya, kota tidak bisa lepas dari proses urbanisasi yang terjadi (Makkelo, 2017). Ibukota Kerajaan Majapahit, Trowulan, merupakan awal berdirinya kota di Pulau Jawa yang sudah menggunakan konsep kota tradisional Jawa. Kota itu memiliki ciri khas kraton untuk pusat pemerintahan dan kediaman raja. Alun-alun dijadikan sebagai pusat kota dan difungsikan sebagai tempat raja dan menteri untuk menghadiri upacara dan kegiatan kerajaan hingga pasar untuk perekonomian masyarakat, masjid dan benteng (Basundoro, 2012: 42).

Kota di Indonesia diklasifikasikan menjadi kota pesisir. Kota pesisir merupakan jalur transportasi dan perdagangan barang jasa dari berbagai negara. Kota pedalaman merupakan kota agraris dan penghasil hasil bumi. Salah satu kota di Indonesia adalah Banten. Kota ini merupakan kota pesisir yang menjadi jalur perdagangan. Hal ini mengakibatkan struktur kota berbeda dengan kota tradisional pedalaman di Jawa. Surakarta merupakan kota pedalaman yang berfungsi sebagai pusat pemerintahan wilayah karesidenan juga untuk mengumpulkan hasil bumi (Susanto, 2017).

Perkembangan kota berlanjut hingga periode kolonial. Kota kolonial merupakan kota yang dikembangkan oleh pendatang dari Eropa di tempat baru saja mereka datangi (Samidi, 2017). Selanjutnya, pendatang Eropa mengembangkan daerah itu menjadi pusat pemerintahan dan pusat imperium bau atau penjajahan hingga perdagangan. Ciri kota kolonial adalah keberadaan rumah residen, rumah 
asisten residen, pemukiman kolonial, pasar, gereja, barak militer, benteng perlindungan, dan gedung Societeiet.

Tujuan penulisan ini adalah untuk mengetahui perkembangan Kabupaten Boyolali ketika berada di bawah pemerintahan Keraton Kasunanan Surakarta hingga mendapat kepercayaan pemerintahan sendiri pada awal abad ke-19. Selain itu, hal ini juga bertujuan untuk mengetahui perkembangan pola pemukiman masyarakat dan mengetahui perkembangan sosial dan budaya yang mempengaruhi dinamika masyarakat Kabupaten Boyolali.

Untuk mencapai tujuan itu, kajian ini memusatkan pada berbagai sumbersumber sejarah. Sumber-sumber itu adalah beberapa arsip sezaman dan buku-buku pendukung. Sumber yang dijadiakn pendukung kajian ini adalah Staatsblaad van Nedherlandsche Indie 1847, Staatsblaad van Nedherlandsche Indie 1874, Rijksblaad van Nedherlandsche Indie 1818 dan Rijksblaad van Nedherlandsche Indie 1919. Selain itu, hal ini juga menggunakan buku-buku tekait, diantaranya adalah Akihary (1988) Architectuur en Stedebouw in Indonesie 1870 - 1940, Zutphen, terbitan De Walburg Press, Soekiman (2000) Kebudayaan Indis dan Gaya Hidup Masyarakat Pendukungnya di Jawa (Awal Abad XVIII-Medio Abad XX), Yogyakarta, terbitan Yayasan Bentang Budaya, Hadinoto 2000. Perkembangan Kota di Jawa Abad XVIII sampai Pertengahan Abad XX, Yogyakarta, terbitan Ombak, Paulus H. (1996) Perkembangan Kota dan Arsitektur Kolonial Belanda di Malang, Yogyakarta, terbitan Andi Press, Jessup, dan Helen, The Dutch Colonial Villa, Indonesia, (MIMAR, No.13/1984).

\section{TEORI DAN METODE PENELITIAN}

Metode penelitian menggunakan metode sejarah dengan berbagai cara. Langkah-langkah tersebut diantaranya adalah pembacaan heuristik, pembacaan kritik sumber, melakuan intepretasi, dan pembacaan historiografi. Pembacaan heuristik dilakukan dengan menyediakan sebuah metode, yakni penyedian sumber data dalam keadaan acak. Sumber data ini masih belum dipilih untuk digunakan atau tidak. Selanjutnya, kritik sumber dilakukan dengan memberikan sebuah langkah yang berupa memilah data baik secara teknis maupun non-teknis. Hal ini bertujuan untuk mendukung penulisan terkait. Selanjutnya, intepretasi dilakukan dengan menafsirkan keterangan yang saling berhubungan secara kronologis agar dijelaskan dengan fakta sejarah yang ada. Teknik analisa menggunakan metode deskripsi kualitatif. Langkah terakhir adalah historiografi. Langkah ini berisi proses penulisan sejarah yang dihasilkan dari data-data yang sudah dikumpulkan berdasarkan fakta-fakta yang telah dipilih. 


\section{HASIL DAN PEMBAHASAN}

\section{Sejarah Kabupaten Boyolali Masa Kolonial}

Pendirian Kabupaten Boyolali tidak dapat dilepaskan dari campur tangan pemerintahan kolonial, terhadap pemerintah Kasunanan Surakarta. Boyolali pertama kali adalah desa yang berdiri di sepanjang jalan utama Surakarta Semarang, Desa tersebut merupakan pos sementara yang didirikan dengan tujuan supaya pengiriman barang dan jasa dari Surakarta ke Semarang maupun sebaliknya. Tujuannya agar dapat berjalan dengan aman. Pos sementara tersebut adalah Pos Tundhan (Staatsblad van Nedherlandsch-Indie 1847 No. 30). Pos Tundhan dikepalai oleh Tumenggung Gunung dibantu oleh Abdi Dalem Gunung bermukim di pinggir jalan raya utama Surakarta- Semarang.

Pos Tundhan ini berlangsung sejak tanggal 12 Oktober 1840 hingga perubahan status menjadi Kabupaten Gunung Pulisi Boyolali pada tahun 1847. Keadaan Pos Tundhan sering terjadi beberapa kekacauan. Hal ini membuat Sunan dan pemerintah Belanda membuat peraturan baru mengenai pemerintahan dhusun atau pemerintahan luar negara. Peraturan tersebut atas dasar pemerintah Bale Mangoe sudah tidak dapat mengurusi masalah pemerintahan. Tanggung jawab pemerintahan di tangan Sunan tetapi dipercayakan kepada Patih dibantu dengan Bupati. Peraturan tersebut muncul tahun 1847.

"Kang kapratjaja angetrapake bebeneran ana ing karaton Soerakarta : 1) ing Kadipaten; 2) ing Pradoto; 3) ing Soerambi apadene bebeneran Bale Mangoe saiki kasowak".

Berdasarkan perjanjian tersebut, Bupati Gunung Pulisi ditetapkan oleh sunan dengan persetujuan Pemerintah Belanda yakni Residen Surakarta. Berdasarkan dari Staatsblad van Nedherlandsch-Indie 1847 No. 30 tersebut, Pemerintah Kasunanan Surakarta membentuk enam daerah Kabupaten Gunung. Hal ini berfungsi sebagai pembantu pelaksana pemerintahan daerah. Para bupati pulisi diberikan tugas mengatasi masalah keamanan dan ketertiban daerah.

Seiring berjalannya waktu dan masalah semakin rumit di Kabupaten Gunung Pulisi, Belanda merubah Peraturan Tanggal 24 Maret 1854 No. 615 menjadi peraturan Pemerintah Kasunanan 1854 No I. Perubahan tersebut tertuang pada Staatsblad van Nedherlandsch-Indie 1854 No. 32. Statua tersebut menjelaskan pendirian Pengadilan Pradata pada setiap kabupaten, dalam mana Bupati Pulisi sebagai residen dan dibantu dengan kaum atau rakyat pribumi. Boyolali pada waktu itu 
merupakan wilayah Kasunanan Surakarta. Hal ini yang menjadikan Pengadilan Pradata tersebut juga didirikan di Boyolali.

"Ing Kaboepaten Klaten, Ampel, Bojolali, Kartosuro, lan Sragen apadene Kawadanan ing Larangan, kadodokan Pangadilan ingaran Pradoto Kaboepaten".

Tujuan pendirian pengadilan ini dikarenakan masih sering terjadi pelanggaran. Pemerintah Kasunanan dan Pemerintah Kolonial pada tahun 1874 menyerahkan sepenuhnya kepada Pradata Kabupaten. Serah terima tersebut terjadi pada tanggal 8 September 1874 dan tertuang pada Staatsblad van Nedherlandsch-Indie 1874 No. 209, yang berisi tentang pelaksanaan ketertiban dan keamanan setiap kabupaten. Tahun 1874 merupakan perdirian Pengadilan Pradata Kabupaten sekaligus penempatan wakil Belanda dengan pangkat Asisten Residen di Boyolali. Dengan adanya asisten residen, hal ini menegaskan adanya Abdi Dalem Kasunanan dan Abdi Dalem Gupermen.

Abdi Dalem Kasunanan di bawah kuasa Bupati Pulisi. Abdi Dalem Gupermen di bawah kekuasaan asisten residen. Sejak dipimpin asisten residen, bupati memiliki dua atasan yakni patih dalem dan asisten residen. Tahun 1918 terjadi penggantian nama Bupati Pulisi dan para abdi dalem menjadi Abdi Dalem Pangreh Praja. Hal ini didasarkan pada Pranata Pepatih Dalem No. 383, Rijksblaad Surakarta 1918 No. 23. Isi dari Pranata Pepatih Dalem tersebut adalah sebagai berikut.

"Para Abdi Dalem Wadono Kaliwon Panewoe Mantri sapanoenggalane,kang saiki kaaranan golongan poelisi, nanging kang koewajiban oega nindakake babagan paprentah ikoe ing samengko djonge golongan Abdi Dalem maoe kasalinan aran : Abdi Dalem Pangreh Projo".

Dengan berubahnya status Kabupaten Gunung Pulisi Boyolali menjadi Kabupaten Pangreh Praja, kepala pemerintahan dipimpin oleh Bupati Pangreh Praja, Bupati Anom, wedana, dan asisten wedana pada tanggal 12 Oktober 1918. Kabupaten Pangreh Praja Boyolali, pada masa kolonial, terdiri dari masyarakat berbagai ragam masyarakat, yakni mulai dari masyarakat Eropa, pendatang, dan masyarakat pribumi. Mereka mewakili budaya dari tiap-tiap golongan. Masyarakat yang beraneka ragam tersebut menyatu dalam satu kota yakni Kabupaten Pangreh Praja Boyolali. Namun, status sosial dari masing-masing golongan berbeda dan ditempatkan di beberapa sudut kota. Hal ini sekaligus menandakan adanya upaya pemisahan atau segresi etnisitas. Fakta ini merupakan suatu kebijakan dari pemerintah kolonial yang berhubungan dengan identitas dalam masyarakat kolonial. 


\section{Perkembangan Arsitektur Indis di Kabupaten Boyolali}

Arsitektur merupakan unsur penting yang mendukung perkembangan sebuah kota. Kota umumnya dapat dilihat dan diberi karakteristik dari identitas gaya bagunan ataupun penataan kota. Gaya arsitektur Eropa yang masuk ke Indonesia tidak dapat berdiri tanpa dukungan dari kolonialisasi bangsa Eropa ke dalam negeri jajahan. Kehadiran gaya arsitektur Eropa yang menojol ini dipadukan dengan arsitektur tradisional baik Jawa maupun Cina. Hal ini merupakan sebuah pembaruan terutama dalam hal gaya hidup. Penyebutan terhadap gaya arsitektur kolonial yang sesuai dengan kondisi setempat berbeda-beda. Menurut pakar, Berlage menyebut sebagai Europe Bouwkunts. Sementara itu, Van de Wall menyebutnya sebagai Indische Huizen (Sumalyo, 1997: 91-93).

Pemerintah kolonial Belanda dalam mendirikan tempat tingal, awalnya, menerapkan gaya arsitektur Eropa. Akan tetapi, gaya arsitektur yang dibawa Belanda ternyata tidak memiliki kesesuaian untuk mengatasi kondisi iklim Indonesia yang berbeda dengan negara Eropa. Belanda harus mengaplikasikan gaya arsitektur Eropa dengan arsitektur Jawa. Hal ini lah yang pada akhirnya sering disebut dengan arsitektur Indis. Arsitektur Indis ini pada akhirnya menjadi salah satu penanda fisik dari kemunculan budaya Indis yang pada perkembangannya akan menjadi budaya kota atau urban culture. Perkembangan arsitektur Indis di Boyolali disesuaikan dengan perkembangan arsitektur di Hindia Belanda secara keseluruhan (Pusparini, et.al., 2006: 11-29). Hal itu dapat dilihat dari periodisasi sebagai berikut, yakni abad ke-16 sampai dengan masa awal 1800, 1800 sampai dengan 1902, 1903 sampai dengan 1920, dan 1920 sampai dengan 1940.

Setiap periode perkembangan arsitektur Indis di Hindia Belanda tidak hanya menghasilkan gaya arsitektur tempat tinggal dan pemerintahan saja. Akan tetapi, tiap periode itu juga memberikan kontribusi yang besar terhadap arsitektur sendiri. Hal ini dimaksudkan sebagai sumbangan dalam sistem atau ekologi artitektur, meliput penataan fisik kota dan manusia yang ada di dalamnya. Sebagai salah satu bukti adalah kelahiran arsitek-arsitek yang mendapatkan pendidikan di Belanda. Mereka memberikan kontribusi bagi Hindia Belanda melalui penataan kota dan karakteristik bangunan kota. Selain arsitek, keadaan tersebut juga muncul Departemen Burgerlijke Openbare Werken (Akihary, 1988: 18).

Arsitektur Indis 1870-1909 di Boyolali, Indische Empire Style. Masa ini sering disebut dengan Indische Empire Style. Periode ini, terutama pada era 1900-an, merupakan awal kebijakan politik liberal. Hal ini dikarenakan kemunculan dan kemenangan golongan liberal di Eropa sehingga modal asing banyak yang masuk 
ke tanah jajahan. Selain itu, gagasan liberalisme juga mulai menghapus sistem culturslelsel. Sebagai pengantinya, undang-undang agrarian diterapkan. Kedatangan masyarakat Eropa ke tanah jajahan karena adanya kebebasan arus modal memunculkan dan membangkitkan sektor industry, terutama perkebunan dan sektor material alam. Sebagai akibatnya, kehadiran mereka juga disesuaikan dengan kebutuhan di Kapubaten Boyolali. Masa akhir abad ke-19, kemunculan ekspansi kolonial Belanda ke Jawa, selain melahirkan budaya kota, memunculkan gaya arsitektur Indis yang pertama, Indische Empire Style atau Dutch Colonial Villa (Hadinoto, 1994: 8).

Gaya arsitektur ini berkembang pada Masa Daendels di Jawa, yakni tahun 19081913. Gaya ini merupakan intepretasi dari gaya arsitektur Eropa pada pertengahan abad ke-18 (Hadinoto, 1995: 131). Hal ini bertujuan untuk menggantikan tempat tinggal yang bergaya landhuizen dengan corak Neo-Klasik. Arsitektur Indies mulai berkembang setelah proses kolonialisasi yang memasuki wilayah pedalaman Jawa. Pada Masa Daendels 1808-1811, mereka mulai mendirikan bangunan tempat tinggal yang bergaya empire Prancis dan bercorak neoklasik. Gaya ini akhirnya disebut dengan landhuizen (Hadinoto, 1994).

Bangunan bergaya Indische Empire di Boyolali diterapkan pada bangunan pemerintahan. Salah satu dari contoh gaya tersebut adalah landraadgebouw atau gedung pengadilan. Gaya arsitektur bangunan itu memiliki karaktersitik diantaranya adalah memiliki garis simetris dengan langit-langit tinggi, terbuka, memiliki plafond tinggi, dan beratap perisai. Selain itu, bangunan tersebut juga memiliki aksesoris seperti barisan kolom berkepala model ionic dan doric pada beranda depan dan belakang. Sementara itu, ruang utama pada jenis bangunan ini diapit dengan kamar bagian kanan dan kiri dengan menggunakan tembok tebal. Penggunaan lantai marmer menjadi ciri yang khas dari bangunan ini dan juga dilengkapi bangunan pendukung seperti galeri (Hadinoto 1996, Soehargo, 1996: 143).

Arsitektur Transisi tahun 1910-1915 di Boyolali, awal abad ke-20 di Hindia Belanda, masyarakat di jawa mengalami berbagai perubahan. Perubahan tersebut terjadi karena perkembangan teknologi dan perubahan social. Sementara itu, perubahan sosial terjadi akibat dari kebijakan politik pemerintahan kolonial Belanda. Kebijakan pemerintah terhadap sistem culturstelsel pada 1830-1870 telah ditiadakan. Pemerintah kolonial menggantinya dengan Undang-Undang Agraria pada masa politik liberal 1870. Sementara itu, tahun 1901-1905 telah ditetap politik 
etis atau balas budi akibat kemenangan golongan liberal. Sebagai akibatnya, undang-undang desentralisasi mulai diberlakukan.

Kebijakan tersebut juga memberikan dampak yang cukup signifikan terhadap arsitektur pembentuk morfologi kota. Kebijakan pemerintah kolonial di Hindia Belanda pada awal abad ke-20 adalah penerapan politik etis. Hal ini bertujuan memberikan kesejahteraan kepada masyarakat pribumi dan Belanda sendiri. Kebijakan tersebut diantaranya adalah edukasi, imigrasi, dan irigasi. Edukasi dilakukan dengan cara mengirimkan anak raja dan priyayi untuk bersekolah di Eropa, yakni Belanda. Imigrasi dilakukan dengan tujuan agar masyarakat pribumi dapat bersahabat dengan masyarakat Eropa atau yang lainnya. Irigasi dilakukan dengan cara pembuatan saluran air dan parit-parit kecil untuk memperlancar arus air karena Belanda menggunakan air sebagai saran dan prasarana yang wajib pada masa itu.

Gaya arsitektur Indis yang berkembang di Kraton Kasunanan juga berkembang di Kabupaten Boyolali. Hal ini terlihat pada bangunan tempat tinggal asisten residen dan bangunan-bangunan lain di Boyolali. Boyolali sebagai bagian wilayah Karesidenan Surakarta berkembang setelah pemerintahan Keraton Kasunanan Surakarta sejajar dengan kota-kota lain seperti Semarang dan Yogyakarta. Perkembangan Boyolali ditandai dengan peningkatan dan pembangunan kota demi kesejahteraan rakyat. Peningkatan tersebut ditandai dengan pendirian bangunan pemerintahan. Selain itu, hal ini juga didukung oleh tempat tinggal mereka. Sebagai akibatnya, gaya arsitektur Barat dengan arsitektur tradisional Jawa mengalami percampuran atau hibrid.. Hal tersebut terlihat pada gedung sekolah, gedung pemerintahan, societeiet, gedung bioskop, rumah dinas, rumah pribadi, rumah sakit, landraad dan lain sebagainya.

Proyek pembangunan gedung-gedung di wilayah Karesidenan Surakarta diserahkan kepada kantor pemerintahan Bale Kretatra dari Kasunanan Surakarta. Sementara itu, pembangunan untuk gubernemen diserahkan kepada Departement Pekerjaan Umum B.O.W atau jasa arsitek profesional lain. Berdasarkan Laporan Keuangan tanggal 1923 dari Residen kepada Kasunanan Surakarta tentang Kantor Asisten Residen di Boyolali, De Sprus menyatakan sebagai Architeek B.O.W Solo, Berkas Mengenai Biaya Pembangunan Kantor Residen di Boyolali Tahun 1923, koleksi BARPUS Provinsi Jawa Tengah No. 500.

Gaya arsitektur bangunan Indis pada masa kolonial banyak yang digunakan sebagai simbol atas status sosial dari masyarakat pribumi. Simbol-simbol status sosial tersebut terlihat pada penggunaan seperti tiang penyangga, hiasan atap, 
makelaar, timpanon, dan fasial board. Kesemuanya itu memiliki simbol sebagai pengungkapkan pilihan gaya hidup pada masanya.

Tiang peyangga menjadi ciri yang khas dari gaya hidup ini. Umumnya, bangunan tempat tinggal dan pemerintahan baik asisten residen, kepatihan, kantoor regent, dan kantoor kontrolir selalu menggunakan tiang penyangga. Tiang Penyangga tersebut bergaya doria, ionic, dan lainnya. Tiang ini terdiri atas susunan kapital, kolom dan pedestal (Soekiman, 2000: 300). Tiang penyangga tersebut memiliki arti kekuatan atau kekuasaan Belanda terhadap penduduk Hindia Belanda yang sangat kuat dan besar.

Hiasan atap dan kemuncak pada setiap bangunan di Kabupaten Boyolali memiliki maksud dan tujuan tertentu sesuai dengan pemilik gedung. Mereka yang memiliki gedung yang terdapat hiasan atap dan kemunak adalah para pejabat tinggi dan masyarakat golongan kelas atas. Setiap bangunan tempat tinggal dan pemerintahan berbeda satu sama lain. Akan tetapi, gaya arsitektural mewakili zaman Eropa kuno. Berikut adalah beberapa hiasan yang dimiliki beberapa rumah Indis di Boyolali dan Hindia Belanda secara keseluruhan adalah mata angin (windwijzer), makelaar, timpanon, dan facial board.

Mata angin umum menjadi penunjuk angin. Penunjuk mata angin ini biasa berada di atap bangunan. Bentuk dari mata angin beraneka ragam sesuai dengan produksi waktu itu. Beberapa kota di Jawa masih ditemukan bagunan yang menggunakan penunjuk mata angin meskipun sekarang hanya digunakan sebagai hiasan atau simbol kemewahan. Sementara itu, bangunan Indis di Kabupaten Boyolali jarang ditemukan penggunaan windwijzer ini. Sementara itu, makelaar merupakan papan kayu dengan panjang satu meter. Benda ini ditempelkan secara vertikal pada fasad depan bangunan. Hiasan ini berada di depan rumah yang berbentuk segitiga bagian dari serambi depan. Hiasan ini di Kabupaten Boyolali cukup banyak digunakan terutama bangunan tempat tinggal dan kantor pemerintahan. Jadi, pengunaan mata angin berbanding terbalik dengan penggunaan makelaar di Kabupaten Boyolali. Makelaar lebih dominan bila dibandingkan mata angin.

Sementara itu, timpanon merupakan hiasan fasade depan tempat tinggal. Hingga saat ini, benda ini masih banyak digunakan pada bangunan, terutama tempat tinggal dan kompleks pemerintahan. Timpanon merupakan istilah lain dari gable, yakni kuda-kuda yang berbentuk segitiga. Umunya, benda inidigunakan sebagai serambi. Facial Board merupakan papan kayu berukir dengan panjang kurang lebih dua meter. Benda ini dipasang untuk menyesuaikan dengan bentuk 
fisik dari tempat tinggal. Hiasan facial board ini berada di bagian depan rumah dan berada di ketinggian yang sama dengan tinggi tembok. Facial board ini biasanya berbentuk rukiran lingkaran dan diapit dua segitiga kecil terbalik. Jadi, pengaruh penggunaan timpanon lebih dominan dan sampai saat ini masih terus digunakan bila dibandingkan dengan facial board (bdk. Estin, Antariksa, dan Suryasari, 2016:57).

Berikutnya adalah hiasan kaca patri. Hiasan kaca patri ini, pada awalnya, hanya digunakan untuk gereja-gereja klasik di Eropa. Hal ini bertujuan untuk memberikan kesan mewah. Sebab, dari hiasan kaca patri itu akan memunculkan pantulan sinar matahari yang dibiaskan pada kaca patri yang berwarna-warni ke dalam ruangan gereja. Perkembangan hiasan kaca patri ini diawali oleh masyarakat Hindia Belanda di Batavia. Mereka menggunakannya sebagai penghias rumah mereka. Sementara itu, bangunan Indis di Kabupaten Boyolali sebagian juga ada yang menggunakan hiasan ini. bahkan, hingga kini, hiasan kaca patri ini masih dipakai sebagai hiasan di gereja.

\section{Pemetaan Kawasan Bangunan Indis di Kabupaten Boyolali}

Seperti yang telah dijelaskan, kota atau Kabupaten Boyolali pada awalnya adalah sebuah desa yang berkembang menjadi kota pemerintahan dan militer. Hal ini terlihat pada pendirian tangsi militer yang lengkap dengan benteng, yang berdiri tahun 1883 dengan nama Benteng Renovatum ${ }^{6}$. Benteng ini berdiri tepat di jalur pos, yakni jalan utama Semarang-Surakarta. Kabupaten Boyolali berbeda dengan Kota Surakarta maupun kota kolonial lain seperti Semarang dan Malang. Perbedaan tersebut didasarkan atas keberadaan alun-alun sebagai ruang publik. Kabupaten Boyolali tidak memiliki alun-alun atau desain alun-alun seperti kota kolonial yang lainnya.

Pusat pemerintahan dan tempat tinggal masyarakat Eropa di Kabupaten Boyolali berada di sepanjang Jalan Raya Pos. Sekarang, tempat itu dikenal dengan Jalan Pandanaran. Jalan itu ditandai dengan keberadan gedung sosieteiet yang menghadap jalan utama. Kabupaten Boyolali sebelum di bawah kontrol pemeritahan kolonial sudah memiliki akses menuju tiga jurusan yakni Surakarta, Semarang dan Magelang. Ketiga askses tersebut memusat ke satu titik yakni pusat Kota Boyolali. Masyarakat Eropa yang tinggal di kota itu tinggal menerusakan penataan kotanya. Penataan kota dilakukan dengan mengikuti pola radial seperti kota-kota di Eropa (Yunus, 2004: 25). 
Pusat pemerintahan dan tempat tinggal masyarakat Eropa di Kabupaten Boyolali berada di sepanjang Jalan Raya Pos atau sekarang dikenal dengan Jalan Pandanaran, dengan gedung sosieteiet menghadap jalan utama. Boyolali sebelum di bawah kontrol oleh Belanda sudah memiliki akses menuju tiga jurusan yakni, Surakarta, Semarang dan Magelang. Ketiga askses tersebut memusat ke satu titik yakni pusat kota Boyolali.

Masyarakat Eropa yang tinggal di kota itu menjadikan alun-alun sebagai pusat kota (Catanse, 1988: 35). Kabupaten Boyolali merupakan salah satu dari enam desa di bawah wilayah Keraton Kasunanan Surakarta. Dalam perkembanganya, daerah ini akhirnya berada di bawah kontrol patih selaku wakil keraton dan asisten residen selaku wakil pemerintah Belanda. Dengan demikian, Bupati Boyolali memiliki dua atasan, yakni patih dan asisten residen. Selanjutnya, dalam hal urusan masyarakat, sistem pemerintahan kota ini dibagi dalam dua urusan, yakni patih yang bertangung jawab untuk urusan internal adat atau tradisi masyarakat. Asisten residen bertanggung jawab mengurusi permasalahan sosial, kriminal, dan hubungan luar dalam masyarakat.

Selain menetapkan pejabat asisten residen di Boyolali, pihak pemerintahan kolonial juga menetapkan kebijakan tentang penempatan Pengadilan Pradhata di setiap desa. Hal ini bertunjuan untuk membantu penyelesaian masalah yang timbul dalam masyarakat. Pengadilan Pradhata ini merupakan pengadilan pertama dan satu-satunya di Kabupaten Boyolali pada masa kolonial Belanda di Surakarta. Hal ini sekaligus menunjukkan pembaharuan terhadap pengadilan yang terdahulu, Pengadilan Surambi (Staatsblad van Nedherlandsch-Indie 1874 No 209).

Gedung pemerintahan yang berada di Kabupaten Boyolali yang lain adalah Kantor Bupati Gunung Pulisi Boyolali atau kantor kabupaten, landraadgebouw, tangsi militer, militaire geneskundige dients, gedung hulppostkantoor, kompleks kepatihan dan kompleks kawedanan. Selain pendirian gedung pemerintahan dan militer yang berpusat di pusat kota Boyolali, kabupaten ini juga memiliki beberapa gedung sekolah. Gedung sekolah itu dibedakan untuk masing-masing golongan masyarakat di Kabupaten Boyolali waktu itu.

Europe School adalah sekolah khusus untuk anak bangsawan Eropa dan elite pribumi. Holland Inlander School adalah sekolah yang dikhususkan untuk anak Indo-Eropa. Sekolah Rakjat yang dirubah menjadi Sekolah Dasar Putri dikhususkan untuk pribumi (Prayudi dan Salindri, 20105). Gedung sekolah tersebut berdiri di Jalan Merapi atau lebih tepatnya sebelah barat pusat Kota Boyolali. 
Segresi identitas dan etnis tgidak hanya ditunjukkan melalui pendidikan, tetapi juga melalui tempat pemakaman. Kabupaten Boyolali memiliki beberapa pemakaman yang diperuntukan bagi masyarakat sesuai dengan status dan golongan sosialnya. Pemakaman itu diantaranya adalah bong, kerkkof, dan pemakaman biasa. Bong dan kerkhof merupakan istilah yang digunakan oleh masyarakat pribumi untuk membedakan antara pemakaman atau kuburan Cina dan Eropa. Keduanya memiliki ciri dan lokasi yang berbeda.

Masing-masing pemakaman memiliki ciri khas. Bong di Kabupaten Boyolali mayoritas berada di atas bukit. Sekarang ini, pemakaman atau kuburan bong berganti nama menjadi Pasar Burung Ngebong. Pemakaman Eropa di Kabupaten Boyolali memiliki keunikan tersendiri. Keunikan itu dilengkapi dengan gapura besar dan bertuliskan "Memento Mori".

Selain sepanjang jalan Semarang-Surakarta atau pusat Kota Boyolali, bangunan berciri khas kolonial juga ditemukan di Jalan Merapi dan Merbabu saat ini. Mayoritas gedung tersebut ditempati oleh keturunan keluarga dari nenek mereka atau beberapa generasi. Nmaun, kini, bangunan itu sudah beralih tangan ke pemerintah maupun swasta. Mayoritas bangunan pemerintahan dan tempat tinggal masyarakat Eropa di Kabupoaten Boyolali berdiri pada tahun 1910-1915. Karakteristik bangunan itu memiliki lantai yang bermotif bunga atau tegel bermotif. Selain itu, plafond tinggi dengan tembok tebal dan penggunaan tiang-tiang penyangga yang kokoh juga menjadi cirinya. Daun jendela pintu yang besar dan tinggi sebagai pemberi pencahayaan sdan penerangan pada ruang pada siang hari adalah karateristik yang tidak tertinggal (Helen, 1984: 35-42).

Beradsarkan pada kasus bangunan Indis di Kabupaten Boyolali tersebut, gaya arsitektur Indis tidak dapat dipisahkan dari lingkungan dan keadana sosialnya, terutama dalam konteks ini adalah budaya Indis sehingga memunculkan gaya bangunan Indis. Definisi budaya Indis sendiri adalah percampuran budaya masyarakat Eropa dengan budaya masyarakat pribumi. Dalam konteks ini, budaya Indis dapat dipanang sebagai budaya hibrid ataupun metizo. Keduanya bercampur untuk menyesuaikan keadaan baik dari segi fisik dan fungsi sosialnya. Dari sisi fisik, aristektur di Kabupaten Boyolali dapat menjadi contohnya. Meskipun demikian, karakteristik fisik ini juga dapat diungkapkan sebagai rangka fungsi ekologis dan kultural atau sosial. Gedung pemerintahan dan bangunan tempat tinggal merupakan dampak dari munculnya budaya Indis. Hal ini ditandai dengan bangunan rumah masyarakat Eropa dan priyayi pribumi yang digambarkan 
mewah lengkap dengan perabotan rumah tangga yang lengkap. Simbol fisik dari benda tersebut menunjukan status sosial yang berbeda.

Gaya arsitektur rumah mereka cenderung mengadopsi unsur tradisional Jawa. Hal ini disesuaikan dengan kondisi iklim setempat atau gaya arsitektur Indis. Pada tahun 1900, kebijakan politik etis mulai diterapkan oleh Pemerintah Hindia Belanda di Jawa. Seiring berjalanya waktu di tahun 1903, kebijakan desentralisasi diberlakukan oleh Pemerintah Belanda di Kota Batavia. Dengan keputusan itu, hal ini memberikan kewenangan untuk kotamadya mengatur pemerintahanya sendiri. Dengan adanya kebijakan tersebut, kotamadya atau gemeente di Jawa berkembang menghasilkan kota kolonial modern.

Kabupaten Boyolali pada awalnya adalah sebuah desa di wilayah Karesidenan Surakarta. Seiring berjalanya waktu, daerah ini berubah menjadi Kabupaten Pangreh Praja Boyolali dengan bupati pertama yakni RNg Sutanegara. Awal pemerintahannya, Boyolali dipegang oleh patih kasunanan. Jabatan itu berada di bawah pengawasan asisten residen selaku wakil dari residen belanda. Secara tidak langsung, pemerintahan Boyolali dipengang oleh asisten residen yang membawahi beberapa kontrolir.

Kedatangan Belanda di Surakarta membawa pengaruh yang cukup besar terhadap perkembangan Kabupaten Boyolali. Pengaruh itu terutama dalam bidang gaya arsitektur bangunan pada abad ke-20. Gaya arsitektur pertama kali adalah indische empire style. Gaya ini diperkenalkan oleh Daendels. Gaya ini memiliki ciri khas, yakni i serambi depan dan belakang, central room dengan kamar samping, memiliki kolom tinggi, dan plafond yang tinggi. Bentuk dan struktur bangunan bergaya Indis juga mempengaruhi gaya hidup masyarakat pendukungnya.

\section{SIMPULAN}

Perkembangan Kabupaten Boyolali terjadi seiring dengan berkembangnya gaya arsitektur Indis di Hindia Belanda pada awal abad XX. Hal tersebut ditunjukan dengan peninggalan bangunan bergaya Indis di Boyolali. Perkembangan kemajuan bangunan pemerintahan dan rumah tinggal masyarakat Eropa di Boyolali juga mempengaruhi kemajuan di bidang pendidikan dan transportasi di Kota Boyolali. Hal ini sebagai akibat dari diterapkannya kebijakan di bidang pendidikan oleh pemerintah Belanda. Kebijakan ini memiliki maksud dan tujuan untuk meningkatkan kehidupan rakyat pribumi dan Eropa khususnya. Sebagai akibatnya, 
beberapa sekolah didirikan dan disesuaikan berdasarkan golongan. Pusat Kota Boyolali memiliki beberapa bangunan, diantaranya villa Merapi, societeiet, tangsi militer, benteng, militaire geneskundige dients dan landraad.

\section{DAFTAR PUSTAKA}

Akihary, H. (1988). Architectuur en Stedebouw in Indonesie 1870 - 1940. Zutphen: De Walburg Press.

Estin, N. Antriksa, dan Suryasari, N. (2016). "Karakteristik Visual Bangunan Kolonial Belanda di Jalan Pemuda Depok", Aristektur e-Journal, 9, (2), 2016, 52-59

Hadinoto (1996). Perkembangan Kota dan Arsitektur Kolonial Belanda diSurabaya 1870 hingga 1940, Surabaya: Lembaga Penelitian dan Pengabdian Kepada Masyarakat Universitas Kristen Petra dan Andi Press.

Hadinoto. (2000). Perkembangan Kota di Jawa Abad XVIII sampai Pertengahan Abad XX, Yogyakarta: Ombak.

Jessup, H. (1984). The Dutch Coloniall Villa, Indonesia, MIMAR, No. 13/1984

Makkelo, I.D. (2017). Sejarah Perkotaan: Sebuah Tinjauan Historiografi dan Tematis. Lensa Budaya, 12, (2) Oktober 2017, 03-11

Prayudi, .G.M. dan Salindri, D. (2015). "Pendidikan pada Masa Pemerintahan Kolonial Belanda di Surabaya Tahun 1901-1942" Publik Budaya, 1, (3), Maret 2015, 20-34

Soehargo, P.H. (1996). Perkembangan Kota dan Arsitektur Kolonial Belanda di Malang, Yogyakarta: Andi Press.

Soekiman, D. (2000). Kebudayaan Indis dan Gaya Hidup Masyarakat Pendukungnya di Jawa (Awal Abad XVIII-Medio Abad XX), Yogyakarta: Yayasan BentangBudaya.

Sumalyo, Y. (1997). Arsitektur Kolonial Belanda di Indonesia, Yogyakarta: Gajah Mada University Press.

Sumidi. (2017). Surabaya Sebagai Kota Kolonial Modern pada Akhir Abad ke-19; Industri, Transportasi, Pemukimandan Kemajemukan Masyarakat, Mozaik Humaniora, 17, (1), 2017, 157-180

Susanto. (2017). Nuansa Kota Kolonial Surakarta Awal Abad XX: Fase Hilangnya Identitas Lokal, Jurnal Sejarah Citra Lekha, 2, (1), 2017, 4-18

Yunus, H.S. (2004). Struktur Tata Ruang Kota, Yogyakarta: Ombak. 


\section{Arsip sebagai Sumber Data:}

Koewajibanipoen Boepati Politie.

Koewajibanipoen Habdidalem Boepati Pangrehpradja.

Rijksblad Soerakarta 1918, No. 23. Tanggal 12 Oktober 1918 angka 383.

Rijksblad Soerakarta 1919, No. 24. Tanggal 12 Oktober 1918 angka 384.

Staatsblad van Nedherlandsche-Indie 1847, No.30.

Staatsblad van Nedherlandsche-Indie 1874, No. 209.

Serat Perdjadjian Dalem Ingkang Sinoehoen Kandjeng Soesoehoenan Kaping VII Kalijan Kandjeng Goeperment Walandi-Nederland Bab Pangadilan Pradoto, Kadipaten, Soerambi.

Serat Kontrak Perdjandjian Ingkang Sinoehoen Kandjeng Soesoehoenan Pakoe Boewono IX Kalijan Kandjeng Goevernement Tahoen 1874 Kamot Ing Serat Staatsblad 1874, No.209.

Serat Angger Ingkang Sinoehoen Kandjeng Soesoehoenan Pakoeboewono VII, (Serat Angger Goenoeng). 